\title{
Controlling the Battlefield: Computing and Operational Command in the Swedish Armed Forces, 1966-1989
}

\author{
Johan Gribbe \\ Div. of History of Science and Technology, KTH \\ 10044 Stockholm, Sweden \\ johan.gribbe@abe.kth.se
}

\begin{abstract}
In the late 1960s, the Swedish Defence Staff initiated the development of a computerized command and control system that was later to be known as the LEO-system. From the mid-1970s to 1989, more than two hundred million SEK were spent on the project, which involved private computer consultants and with military staff officers acting as project leaders and customers. In the end, however, only the intelligence application was introduced and put into operational use in the Swedish intelligence service during the 1990s. This paper will tell the story of the LEO-system and outline some of the reasons behind its failure. It is based on a witness seminar held at the Swedish Armed Forces Headquarters in Stockholm on January 15, 2008.
\end{abstract}

Keywords: Cold war, main frame computer, military technology, security.

\section{Introduction}

In the late 1960s, the Swedish Defence Staff initiated the development of a computerized command and control system that was later to be known as the LEOsystem. The decision followed a reorganization of the national command structure and the system was intended to help central and regional military headquarters conduct wartime operations. Each headquarter was to have one LEO terminal system, with a number of workstations, containing information about all aspects of the battlefield. Information about friendly and enemy forces, fuel and ammunition supplies, were to be stored in a central database and a secure messaging system was to provide fast and reliable communications. Additional applications were developed to handle computations and simulations of transports and mobilization times. From the mid-1970s to 1989, more than two hundred million SEK were spent on the project, which involved private computer consultants and with military staff officers acting as project leaders and customers. In the end, however, only the intelligence application was introduced and put into operational use in the Swedish intelligence service during the 1990s.

This paper will tell the story of the LEO-system and outline some of the reasons behind its failure. One problem, that many insiders point out, was the considerable passive resistance which the system encountered from both end users and senior commanders when new computer technology was to be introduced in old organizational 
structures. The critical problem in this case was security. To develop an integrated and computerized command system meant that highly classified information about war plans, communications and intelligence was concentrated in a single computer system, which run counter to the fundamental military principle that an officer should know no more than absolutely necessary to execute the task assigned to him. Measures developed to control access, and to guarantee electronic security, provided little assurance to critics within the officers corps.

Other problems concerned the core technology involved. During more than twenty years of development, the LEO-system survived several different generations of computers, from the mainframes of the early 1970s to the personal computers of the late 1980s, with the basic system architecture intact. How did these technology shifts affect system development? Or put differently: How come the project was not cancelled but rather re-equipped with new computer hardware despite the apparent problems? Finally, it could be argued that the reason behind its failure was cultural and related to the grand ambitions of the system. In fact, there are many similarities between the LEO command system and the management information systems (MIS) developed in the private sector during the second half of the 1960s. The similarities concern both the basic technology and the overall function of the system, and the reasons behind the failures of LEO and other MIS-systems are probably similar [1].

Some parts of the LEO command system are still in use within the Swedish military intelligence (MUST) and all written documentation about the system and its development is classified. Instead, this paper is based on oral accounts given at a witness seminar held at the Swedish Armed Forces Headquarters in Stockholm on 15 January 2008 [2].

\section{Project Initiation and Early Tests}

In 1966, the command structure of the Swedish Armed Forces was reorganized. Sweden was organized in so called military areas. The general in command of a military area commanded the army divisions stationed in the region, the regional naval command and the regional air defence sector. The commander answered directly to the Supreme Commander. Each area was named according to the geographical area it covered. After the 1966 command reform, there were eight military areas, from the Upper Norrland Military Area (Övre Norrlands militärområde) in the north to the Eastern Military Area (Östra militärområdet), covering Stockholm and most parts of Södermanland and Uppland to the Southern Military Area [3]. In connection to this reorganization of regional command, the Supreme Commander ordered an investigation of a possible computerization of the military command structure. In terms of ideas, the project had close connections to the Management Information Systems (MIS) that were introduced at this time in many large private corporations. For a discussion on Management Information Systems in private industry, see Gustav Sjöblom's contribution to this volume [4].

Work on the new project was formally initiated in 1969-70. As the new system was intended as an integrated operational command, control and communications system for all three service branches, overall systems responsibility was given to the head of the Operations section within the Defence Staff (Försvarsstabens Sektion III). 
This department was responsible for warplanning. Military officers from deparments within the Operations section acted as "buyers", specifying the functionality of the system, working in team with the computer specialists in charge of applications development. Meanwhile, personnel from the Data processing department of the Defence Staff (Försvarsstabens ADB-avdelning) and computer consultants from private companies were to handle systems development. A military officer, colonel Torbjörn Ottosson, was put in charge of applications development. In 1970, the project was formally named LEO after a headquarters command excercise with the same name. This division of labour between military officers, acting as customers of the applications and subsystems developed for their particular area of responsibility, and the computer specialists in charge of software development - with no project manager in charge of the project - was later to be a subject of much debate and criticism.

Technologically, the LEO systems architecture was closely linked to the large mainframe computers that appeared in the mid and late 1960s. Each headquarter was to have one terminal system, with a number of workstations connected to it, containing information about all aspects of the battlefield. Information about friendly and enemy forces, fuel and ammunition supplies, was to be stored in a central database and a secure communications system, the LEO Message Control System (LEO:MCS) was to provide fast and reliable communications. Information about military forces, their level of preparedness, their fighting values and losses was handled in an application called LEO:SK. Another important area in which computer power could support decision making was transport planning, handled in an application called LEO Transport Planning (LEO:TP) that contained maps and information about roads and railroads and their capacity. Using the transport planning application, military commanders could calculate alternate routes or the consequenses of the enemy knocking out a bridge or a railroad junction. The intelligence application, called LEO:UND, was essentially a mirror image twin of these applications, intended to store the same information about the enemy, his supplies and his fighting capacity.

\section{Computer Procurement}

A major user of mainframe computers in the military organization was the the National Service Administration in need of computing and storage capacity to process information about the tens of thousands of young men who did their compulsary military service each year. The computing division of the service administration in Kristianstad had aquired a Burroughs B2500 mainframe computer that was used to test an early version of LEO. A particular advantage of the Burroughs mainframe system was that it already contained a powerful data base handler colled FORTE. After an initial period of testing, formal technical and operational specifications of the LEO computers were issued in 1977-78. While most of the software development hade been handled by personnel of the computer department (ADB-avdelningen), or external consultants tied to it, the procurement of systems hardware was handled by the Swedish Agency for Public Management (Statskontoret) in cooperation with the Swedish Defence Material Administration (Försvarets materielverk, FMV). In the 
end, four competing companies/systems remained: Norsk Data/Nord-series, Datasaab/Censor 932, DEC/VAX-11 and minicomputer from Burroughs. In November 1979, Norsk Data was chosen as the supplier and three of its Nord 100 computers were ordered to be used with Alfaskop data terminals.

At the same time the first problems started to appear. By the late 1970s, the LEOproject had already dragged on for almost a decade without an operational system even being close to completion. Several technical problems had come to light. A major problem was still limitations in computer graphics and presentation technology and in addition, the security of information stored in the system started to be a concern. It was clear that the LEO-system, while functioning at exercises, could not live up to previous expectations. Gert Schyborger, then project manager at the Defence Staff, recalls two opposing sides at this time. On the one hand, those who considered the problems to be causes of delay, not reasons to discontinue the entire project. According to them, the project should be allowed to continue with the hopes of a technological fix along the way. On the other hand, those who considered the whole idea of a central computerized system for operational command to be premature and who thought that it should be abandoned right away. The dispute ended in what could be labelled an organizational compromise. The position as project leader was separated from the position as chief of the operations section within the Defence Staff, and a special project manager was appointed. The task of implementing the LEO-system on a smaller scale, while awaiting new technological developments, was assigned to colonel Orvar Lundberg in 1981. The fundamental issues, however, were not resolved and the project was to become a source of conflict throughout the 1980 s.

This internal debate on the future of the system coincided with shifts on several important positions within the military high command. Throughout the project supreme commander general Stig Synnergren had been a keen supporter, but he was replaced in 1978 by the more sceptical army general Lennart Ljung. The most important shift, however, took place at the position as head of the Defence Staff where vice admiral Bror Stefenson succeeded Bengt Schuback in 1981. Stefenson, like a number of other high-ranking officers, believed LEO to be a waste of both time and money and openly declared to the new project manager Orvar Lundberg that "he did not believe in automated computer processing and that there should be no new system". By this time, however, the decision to build the system was firmly anchored in decisions within both the military high command and the government. Stefenson did not have the authority to discontinue the project, but he did control the funds and during the course of the 1980s, Lundberg saw his project increasingly stripped of economic resurces and manpower. Behind the resistance from Stefenson and other senior officers, however, lay deeper concerns than just the short term financial aspects of the project. Which would be the wider consequences of introducing computer technology in the military command structure?

\section{Security Problems and the End of the Project}

On the one hand, the idea of commanding the armed forces through an integrated and centralized computer system - with the supreme commander and his staff in the 
center - seemed almost congenial with the hierarchic nature of the military command structure. If properly used, computer technology could be a means of strengthening and consolidating the traditional military chain of command. On the other hand, however, the system architecture violated other equally important military principles in a way that was not obvious when the system was first conceived. To develop a computerized command system meant that highly classified information about war plans, mobilization schemes, communications and intelligence was gathered in a single computer system, something which ran counter to the fundamental rule of military security that an officer should know no more than absolutely necessary to execute the task assigned to him. What would, for example, prevent a military officer from tapping the system and handing over classified information to the enemy? And how could orders issued within the system be authenticated? Wouldn't it be possible for lower level commanders in wartime to issue orders that were either outside their area of responsibility or, in worst case, deliberately false and misleading?

These weaknesses could not easily be corrected without changing the overall systems architecture. Measures developed to control access, and to guarantee the security of classified information stored in the system, provided little assurance to the critics within the organization and these problems were probably an important reason behind the considerably passive reaction the project encountered among influential senior commanders. Another problem subject to much debate at this time was that of electronic security. In the late 1970s, it was discovered that computers, and monitors in particular, emitted relatively strong electronic signals that could be picked up and used to tap the system of secret information. The resulting measures to secure the system caused the cost of systems hardware to increase threefold, while the cost of communications and installation increased almost by a factor of ten, causing a severe strain on the already limited project budget and resulted in further delays. This increase in the cost of communications resulted in large part from the addition of a fiber optic communications network, a new and unproven technology at that time.

Despite the security problems, the dramatic cost increases and the lacking support from senior military commanders, the project dragged on during the first half of the 1980s under the leadership of Orvar Lundberg. Development work was allowed to continue, the many internal computer programmers and external consultants tied to the project were paid, and several new applications were added to the system. A limited test version of the system called LEO-80 was installed at the military headquarters in Stockholm, beginning in 1981. However, despite a formal decision in 1984 to implement the system, no additional funds were made available to buy new hardware and more computers that could meet the new security standards.

This situation continued until 1987 when the most outspoken critic of the project, vice admiral Bror Stefenson, finally retired and was replaced by general Torsten Engberg as head of the Defence Staff. Engberg had a more sympathetic attitude towards the project in general and decided that the by now largely dormant LEOsystem should be refurbished with new hardware and put into operational use. The annual budget assigned to LEO was doubled to thirty million SEK and to mark the shift the new name LEO-85 was decided. At the same time, the project management was renewed when commander Lars-Erik Hoff, who had served under Engberg at the navy staff, replaced Orvar Lundberg as project manager. Hoff faced a fundamentally different situation than his predecessor both in terms of funding and support, and a 
period of rapid expansion ensued. After less than two years, in 1989, all regional headquarters had been equipped and the system was declared operational.

In the end, however, this proved to be only a temporary success. In 1994, work on a replacement system called ORION was initiated. Originally, ORION like LEO was intended to be a secure wartime communication system for military operational command, capable of handling both open, secret and top secret information, but this goal was never achieved. During the 1990s, the system, as used by central and regional headquarters, had gradually evolved into a system for the handling of intelligence. In 1999, development work on all ORION applications but the intelligence subsystem was discontinued, almost thirty years after the LEO project was initiated. This latter part of the system is still in use within the Swedish military intelligence organization.

Acknowledgments. I am grateful to Handelsbankens forskningsstiftelser for supporting the research for this paper. I am also grateful to my colleagues within the project, "Precursors of the IT Nation: Computer Use and Control in Swedish Society, 1955-1985" for comments on earlier versions of the paper.

\section{References}

1. Haig, T.: Inventing Information Systems: The Systems Men and the Computer. Business History Review 75(1), 15-60 (2001)

2. Gribbe, J.: LEO: Databehandling och operativ ledning inom försvaret, 1972-89: Transkript av ett vittnesseminarium vid Högkvarteret i Stockholm den 15 januari 2008. Avdelningen för teknik- och vetenskapshistoria, KTH, Stockholm (2008)

3. Cars, H. C., Skoglund, C., Zetterberg, K.: Svensk försvarspolitik under efterkrigstiden. Probus förlag, Stockholm (1986)

4. Sjöblom, G.: The Totally Integrated Management Information System in 1960s Sweden. In: Wangler, B. (ed.) HiNC3. IFIP AICT, vol. 350, pp. 83-91. Springer, Heidelberg (2011) 